DOI https://doi.org/10.32782/2305-9389/2020.22.13

УДК 323.27: 316.4

Перфільсва Анастасія,

кандидат політичних наук, дочент, доцент кафедри права, політології та міжнародних відносин Університету імені Альфреда Нобеля

\title{
КОНЦЕПЦІЯ ТУРБУЛЕНТНОСТІ В ПОЛІТИЧНІЙ НАУЦІ
}

У статті представлено спробу узагальнити илях термінологічної концептуалізації проблеми кризової нестійкості суспільного розвиткуу політичній науці. Здійснено спробупорівняння понять «криза», «ризик», «хаос», «турбулентність». Установлено, щзо початкове використання у суспільних науках поняття «турбулентність» мало яскравий метафоричний характер, який деінде залишається й понині. Проте нині очевидною є потреба у відході від метафоричності поняття і концептуалізації його змісту відповідно до сутнісних ознак соціальнополітичного середовища $i$ завдань, щฺо постали перед політичною наукою. Поняття «турбулентність» є шириим за замістом і включає у себе феномени ризиків, небезпек, загроз. Нині найбільшу частку концепцій турбулентності присвячено світовому або міжнародному виміру політичної дійсності, проте навіть вони вирізняються різнорідністю та суперечливістю. Під час інтерпретації турбулентності відбувається змішання кониептів «турбулентність», «криза», «хаос», «небезпека», «ризик», «загроза». Тож актуальним завданням сучасної політичної науки є виявлення концептуального змісту категорії «турбулентність» із позицій можливості ї̈ використання в апараті сучасної політичної науки для дослідження процесів, які відбуваються на різних рівнях соціально-політичної реальності. Концепџія турбулентності дає змогу розглядати дестабілізацію в політичній системі у більш циіннісно нейтральному світлі, зосереджуючись передусім на динаміці, на змінах. За допомогою кониепції турбулентності можливим стає аналітичне дослідження рушійних сил змін у політичних системах, тож теоретичне осмислення турбулентності стає очевидним здобутком сучасної політичної науки, оскільки дає змогу вдосконалити понятійно-категоріальний апарат та інструментарій дослідження політичної динаміки. Подальша концептуалізація категорії «турбулентність» сприятиме, відповідно до сучасного рівня розвитку наукового знання, інтерпретації динаміки і прочесуальності явищ соціально-політичної реальності на всіх рівнях (локальному, національному, регіональному, глобальному, міжнародному).

Ключові слова: турбулентність, криза, хаос, нелінійний підхід, невизначеність, політична динаміка, процесуальність.

\section{Perfilieva Anastasiia. The concept of turbulence in political science}

The article presents an attempt to generalize the way of terminological conceptualization of the problem of crisis instability of social development in political science. An attempt is made to compare the concepts of "crisis" - "risk" "chaos" - "turbulence". It is established that the initial use of the concept of "turbulence" in the social sciences had a vivid metaphorical character, which remains elsewhere to this day. However, now there is obviously a need to move away from the metaphorical nature of the concept and conceptualize its content in accordance with the essential features of the environment and the challenges facing political science. The concept of "turbulence" is broader in scope and includes the phenomena of risks, dangers, threats. Today, most concepts of turbulence are devoted to the global or international dimension of political reality, but even they are heterogeneous and contradictory. When interpreting turbulence, the concepts of "turbulence", "crisis", "chaos", "danger", "risk", "threat" are mixed. Therefore, the urgent task of modern political science is to identify the conceptual content of the category "turbulence" from the standpoint of the possibility of its use in the apparatus of modern political science to study the processes occurring at different levels of socio-political reality. The concept of turbulence allows us to consider destabilization in the political system in a more value-neutral light, focusing primarily on the dynamics, on change. With the concept of turbulence it becomes possible to analyze the driving forces of change in political systems, so the theoretical understanding of turbulence becomes an obvious achievement of modern political science, as it improves the conceptual and categorical apparatus and tools for studying political dynamics. Further conceptualization of the category "turbulence" will contribute in accordance with the current level of scientific knowledge of the interpretation of the dynamics and procedural phenomena of sociopolitical reality at all levels (local, national, regional, global, international).

Key words: turbulence, crisis, chaos, nonlinear approach, uncertainty, political dynamics, procedurality.

У сучасній політичній науці очевидною є наявність помітної кількості досліджень, присвячених конкретним проявам турбулентності, особливо це стосується міжнародного виміру політики, коли сучасні масові протести розглядаються в контексті активізації турбулентності у світовій політиці або вивчається трансформація міжнародного середовища з виокремленням певних етапів у цьому процесі. Водночас концепт «турбулентність» не отримав дотепер чітких параметрів та однозначного змістовного наповнення, що сприяло б подальшому поширенню його використання як аналітичного інструмента. 
Нині існує загроза «суб’єктивізації» турбулентності для виправдання та пояснення прорахунків у політиці, руйнівних наслідків діяльності політичних лідерів із метою забезпечення бодай найменшої легітимації. Для мінімізації таких загроз доцільними є подальші комплексні дослідження турбулентності та концептуалізація поняття на основі врахування основних здобутків методологічного забезпечення розвитку сучасного наукового знання та змісту політичного і політологічного дискурсів.

Існує думка про те, що в сучасних суспільних науках поширеною практикою є використання визначення політичних процесів як турбулентних як метафори [1, с. 18]. Метафоричність наукового використання даної категорії передбачає, на думку Д.Б. Абдурахманова, багатогранність феномену, який позначає ця категорія. Це є цілком закономірним, оскільки поява і закріплення цієї категорії відбулося в межах становлення нової наукової парадигми сучасної науки - синергетичної, тож вихід за межі існуючих теоретичних концепцій i, як наслідок, поява цієї парадигми $є$ очевидним результатом концептуального аналізу логіки розвитку наукового знання, яка демонструє, що реальність є більш складною та багатоаспектною, ніж іiї відображення у структурі теоретичного знання. У цілому наукове знання, навіть найрозвинутіше, відтворює не об'єктивну реальність саму по собі, а лишень ті зв'язки та відношення, які дають змогу пізнати наявні емпіричні, логічні, математичні та експериментальні засоби [2, с. 111]. Теорія має справу не з реальним світом, а з моделлю, тобто світом, яким він постає через наявні логіко-математичні та експериментальні засоби, ці останні змінюються разом із розвитком людства у цілому та окремого індивіда як суб'єкта пізнання зокрема. Тож поява наукових парадигм $є$ неминучою і супроводжує всю історію науки. Актуалізація нелінійної методології пов'язана з особливостями сучасної епохи і синергетикою, підводячи до розуміння складності та нелінійності світу, презентує його як єдність порядку і хаосу, в якому стабільність є моментом нестабільності [2, с. 111-112]. Увага науковця прикута не стільки до існуючого, скільки до виникаючого, як-то породження порядку з хаосу. Синергетика затвердила новий тип науковості на основі ймовірнісних уявлень. Це стало величезним проривом для дослідження політичної динаміки, процесуальності у політичній науці. Помітним кроком на цьому шляху стали поява і поширення концепції «турбулентності».

Нині найбільшу частку концепцій турбулентності присвячено світовому або міжнародному виміру політичної дійсності, проте навіть вони вирізняються різнорідністю та суперечливістю. Під час інтерпретації турбулентності відбувається змішання концептів «турбулентність», «криза», «хаос», «небезпека», «ризик», «загроза», що засвідчує проблему використання концепту «турбулентність» як політологічного інструменту для підвищення веріфікованості та евристичності політичного знання. Тож метою представленого дослідження є виявлення концептуального змісту категорії «турбулентність» із позицій можливості її використання в апараті сучасної політичної науки для дослідження процесів, які відбуваються на різних рівнях соціально-політичної реальності.

Найбільшу кількість теоретичних досліджень турбулентності присвячено проблемі турбулентності у світовій політиці (Дж. Розенау, Х. Маулль, М. Ніколсон, Дж. Аррігі, Д. Єфременко, С. Пономарьова, О. Свдоченко, В. Андрущенко, А. Багінський, І. Чихарьов, Д. Полулях та ін.). На аналізі турбулентності у соціальних системах у цілому зосереджувалися Ф. Емері, Е. Тріст, О. Яницький, М. Негрова та ін. Водночас дотепер зберігається певна обмеженість використання категорії «турбулентність» у дослідженнях динаміки політичних систем. Оскільки «політична система» - базове поняття сучасної політичної науки, а категорія «турбулентність» дає змогу відповідно до сучасного рівня розвитку наукового знання інтерпретувати динаміку і процесуальність явищ соціально-політичної реальності, доцільною $\epsilon$ подальша концептуалізація поняття «турбулентність» для можливостей саме політологічного аналізу процесів на всіх рівнях (локальному, національному, регіональному, глобальному, міжнародному).

Уже на світанку людської історії формується уявлення про хаотичні та непередбачувані процеси, більшість 3 яких викликала острах та занепокоєння, що підігрівалися міфологізацією і віщуваннями майбутніх катаклізмів. Пророцтва релігійних діячів, учення філософів, а часом навіть концепції вчених містили у собі описи подій, які поставали страшними наслідками нерозважливої або безвідповідальної поведінки людини. Оскільки різноманітні катаклізми супроводжують людство протягом усієї його історії, то із раціоналізацією світосприйняття і прагненням об'єктивізації уявлень про світ людина не змогла оминути дослідницькою увагою різноманітні кризові явища у суспільно-політичному житті. У цілому рубіжним часом появи саме наукового підходу до розгляду кризової нестійкості суспільнополітичного розвитку стає XIX століття, коли до понятійно-категоріального апарату суспільствознавчих студій потрапляють терміни «криза», «революція». Від початку подібні терміни пов’язувалися 3 описом соціокультурної динаміки, політичних та економічних потрясінь у житті окремих суспільств. Певним маніфестом термінологічного поступу категорії «криза» стає філософська праця «Присмерк Європи» Освальда Шпенглера. Дискусії довкола ідей, викладених у цій роботі, певною мірою стали 
поштовхом, зокрема, для соціологів і політологів у їхній дослідницькій увазі до кризи в житті суспільства. Чи не найпомітнішою постаттю серед науковців, які звернулися до цієї проблеми у XX столітті, $\epsilon$ Питирим Сорокін, роботи якого «Криза нашого часу», «Соціальна та культурна динаміка» закладають міцні підвалини наукового вивчення кризових явищ, що постають як невід’ємні складники суспільного розвитку.

Із другої половини XX століття соціальні науки звертають увагу на той факт, що такі ознаки кризи, як бурний розвиток подій, нестабільність, невизначеність, непередбачуваність, із винятків перетворюються на норму життя у сучасному світі. Для опису стану суспільства і світу в таких умовах усе частіше починають використовувати поняття «ризик». Якщо проаналізувати історію становлення та розвитку наукових досліджень із проблематики політичного ризику, то стає очевидним, що протягом другої половини XX століття відбувалося постійне розширення поняття «політичний ризик» [3, с. 56]. Певною квінтесенцією такого стану постають становлення теорії «суспільства ризику» та інституціоналізація окремого дисциплінарного напряму, присвяченого вивченню політичних ризиків, - політичної ризикології. Відповідно до цих підходів, сучасне суспільство - це суспільство ризиків, в якому ризики виробляються постійно на легітимній основі в рамках інституціональних структур у всіх сферах життєдіяльності суспільства, що зумовлює потребу в науковому вивченні цього процесу за допомогою політичної ризикології. Остання, виокремивши своїм предметом політичний ризик, визначила його як «категорію політичної науки, яка відображує характерні особливості сприйняття зацікавленими суб'єктами суспільно-політичних відносин об'єктивно існуючих невизначеності та конфліктності, іманентно притаманних процесам цілепокладання, управління, прийняття рішень, оцінювання, що обтяжені можливими загрозами та невикористаними можливостями» [4, с. 262]. Тож очевидне визнання надзвичайної суперечливості, динамічності та складності суспільного життя вимагає оновлення наукових підходів до вивчення таких реалій. Саме тому зміна парадигми наукового дослідження, переосмислення місця та ролі усіх суб’єктів у соціально-політичному просторі стає актуальним завдання сучасної політичної науки. Відправною точкою пошуку шляхів для вирішення такого завдання стає нелінійний підхід до розуміння хаосу. Інтерес до проблеми хаосу значно збільшується після публікації праці І. Пригожіна та I. Стенгерса «Порядок з хаосу» у 1979 р., основна ідея якої полягала у тому, що детерміністський опис не може бути використаний для розгляду систем, які перебувають у нестійкому стані [5]. Поступово в середовищі соціологів, економістів, політологів, філософів, міжнародників популяризується категорія «хаос» для опису соціальних систем. Прихильники перенесення положень нелінійних підходів до розгляду соціальних систем підкреслюють, що хаос - невід’ємна характеристика світу: світ приречений бути хаотичним, оскільки в ньому одночасно діє величезна кількість різноманітних акторів, кожен з яких керується різними цінностями та цілями. Сучасний стан суспільства змушує відмовитися від традиційних уявлень про кризу як тимчасовий стан, що порушує первинну стабільність, оскільки насправді все відбувається навпаки: стабільність $є$ тимчасовим станом суспільства, тоді як хаос - нестабільність ось справжній перманентний стан. Тож сучасне наукове знання про кризову нестійкість суспільного розвитку проростає крізь фундаментальне зміщення акценту від сприйняття кризи та нестабільності як аномалії до інтерпретації кризового стану як атрибутивної характеристики усієї системи суспільних відносин. Нестабільність не є тимчасовим скороминущим явищем, це не аномалія, а норма, i завдання політики - забезпечувати шляхи адаптації, пристосування до реалій такого хаосу. Нелінійний підхід і теорія хаосу презентували нове, більш адекватне сучасним умовах уявлення про соціальні системи, в яких динамічність та різнорідність визначають їх нестабільність, нестійкість і некерованість. У межах такого дискурсу з'являється категорія «турбулентність», здатна максимально коректно відобразити стан системи як вихідної умови соціально-політичної динаміки. Само слово «турбулентність» уперше було використано в гідродинаміці, де під нею розумілося утворення у потоці рідини хаотичних вихорів унаслідок змін швидкостей в окремих областях. Початкове використання у суспільних науках слова «турбулентність» мало яскравий метафоричний характер, який деінде залишається й понині. Проте цілком очевидною $€$ потреба у відході від метафоричності поняття і концептуалізації його змісту відповідно до сутнісних ознак середовища і завдань, що постали перед політичною наукою. Серед науковців, котрі усвідомили евристичність категорії «турбулентність» у соціальних науках, необхідно виокремити представників організаційної теорії Ф. Емері та Е. Тріста. У 60 -х роках XX століття зазначені автори публікують статтю, в якій, розглядаючи середовище функціонування організацій, виокремлюють його певну форму, визначаючи ії̈ як турбулентну. На їхню думку, турбулентне середовище характеризується високим ступенем складності, динамізму та гетерогенності, що $є$ серйозною перешкодою для розвитку організації [6]. Із часу оприлюднення цього узагальнення стосовно соціальних практик минуло понад 50 років, але дотепер складно говорити про єдину концепцію криз, хаосу і турбулентності у суспільно-політичних 
науках. Проаналізувавши наявні підходи, Д.С. Полулях виокремлює дві традиції інтерпретації категорії «турбулентність» у дослідженнях соціально-політичного розвитку. Перша розглядає турбулентність як перехідний етап від одного якісного стану суспільства до іншого. Друга традиція не надає кризі й турбулентності великого значення, вбачаючи в них тимчасові незручності перед поверненням системи до первинного докризового стану, тож турбулентність як явище може бути характерним для будь-якого історичного проміжку, що великою мірою робить можливим використання такої категорія для презентації нелінійного підходу в дослідженні політичної реальності. Обидві традиції можуть дробитися і множитися на основі різного прочитання змісту соціального процесу. Так, традиція, яка пов'язує кризу зі змінами, знаходить свій розвиток в есхатологічних поглядах або у стадіальному уявленні про соціальнополітичний процес [7, с. 32].

Найбільш очевидними спробами подолати певну розмитість та несталість уявлень про турбулентність у політиці залишаються дослідження середовища міжнародних відносин та світової політики. Здебільшого йдеться про підкреслення ознак світової політики або специфіки міжнародного середовища, які постають нестабільними, хаотичними, дезорганізованими. Часто турбулентність за змістом сполучається 3 поняттями «безлад», «анархія», «потрясіння», «сум'яття». Водночас усе більш усвідомленим є розуміння турбулентності як категорії, що позначає не просто відсутність стабільності. Сучасні дослідження турбулентності багато в чому спираються на творчий доробок у цьому питанні Дж. Розенау, тож і відправною точкою концептуалізації «турбулентності» доречно розглядати погляди Дж. Розенау. На його думку, турбулентність передбачає наявність «напруги та змін, коли структури і процеси, які зазвичай підтримують політику, нестійкі і в них відбувається перебудова» [8, с. 123]. Але не будь-які прояви нестабільності або кризи є ознакою турбулентності. Турбулентність передбачає настання нового порядку, формування нового світу з новими правилами та законами. Водночас у сучасній політичній науці турбулентність асоціюється не стільки зі змінами, скільки з невизначеністю, варіативністю майбутнього стану системи. Тож наслідки турбулентності $є$ невизначеними, очікування - несправдженими, а результати активізації драйверів політичної динаміки - нестійкими. Невизначеність - непередбачуваність - непрогнозованість як ознака турбулентності розуміється в сучасній політичній науці як якість, що визначає ускладненість довготермінових прогнозів і уявлень про майбутнє. Тож тут прослідковується очевидний зв'язок самої категорії із синергетичною парадигмою, для якої ключовим постулатом $\epsilon$ нелінійність та багатоваріантність процесів, результат яких не $є$ наперед визначеним. Окрему увагу доречно приділити такій ознаці турбулентності, як іiі тривалість, яка викликає доволі активні дискусії серед науковців. Одна група наполягає на тому, що турбулентність - відносно короткий за термінами період переходу від одного стану системи до іншого. Інші наполягають на тому, що турбулентність здатна поставати новим, стійким станом системи, який одночасно $є$ і джерелом, і наслідком змін у політиці. Остання думка повною мірою перегукується з ідеями Дж. Розенау, котрий зазначав, що турбулентність репрезентує мінливість і може сама сприяти подальшим змінам [8, с. 61]. Водночас для турбулентності характерною є суперечливість, причому це стан множинності суперечностей, а не якоїсь однієї. Розгортання турбулентності передбачає зіткнення і конкуренцію трендів у політичному процесі, коли тенденція зіштовхується з контртенденцією, і результат такого зіткнення $\epsilon$ непередбачуваним. Тож турбулентність завжди продукує стан невизначеності. Це складне, рутинне явище, котре не передбачає однозначного завершення інновацією. Важливим є неототожнення турбулентності з хаосом. Свого часу на цьому наголошували I. Пригожин та І. Стенгерс, коли зазначали, що «складність руху ще не $\epsilon$ достатньою, щоб його можна було вважати хаотичним» [5, с. 380]. Складність турбулентності не передбачає втрату усвідомлення спрямованості або цілепокладання у діях політичних акторів, і це відрізняє ії від хаосу. Водночас завжди зберігається ризик переходу турбулентності в хаос. Існує навіть думка, що «хаос - це найбільш сильний прояв турбулентності, який супроводжується найбільшими ризиками і максимальним ступенем невизначеності» [9].

Для опису соціальних, політичних, економічних відносин часто використовують поняття «небезпека», «загроза», «ризик», які в деяких аспектах схожі з турбулентністю. Проте у цілому поняття «турбулентність» $€$ ширшим за замістом і включає у себе феномени ризиків, небезпек, загроз. Концепція турбулентності передбачає розгляд дестабілізації в більш ціннісно нейтральному світлі, зосереджуючись передусім на динаміці, на змінах. За допомогою концепції турбулентності можливим стає аналітичне дослідження рушійних сил змін у політичних системах, тож теоретичне осмислення турбулентності стає очевидним здобутком сучасної політичної науки, оскільки дає змогу вдосконалити понятійно-категоріальний апарат та інструментарій дослідження політичної динаміки. Турбулентність - це динаміка змін у системі, яка характеризується перманентною або періодичною нестабільністю, амбівалентністю та невизначеністю процесів. Турбулентність - це не лише реальний, а й дискурсивный феномен. 
В умовах еволюції засобів медіа й особливостей сприйняття людиною кризових явищ дискурс і метафора турбулентності починають відігравати суттєву роль, впливаючи на осіб, що приймають політичні рішення [7, с. 54]. Тож подальші наукові розвідки, очевидно, здійснюватимуться у напрямі конкретизації впливів турбулентності на процес прийняття та реалізації політичних рішень, що надасть концепції турбулентності ще більшої інструментальності вже в прикладному, а не лише аналітичному сенсі.

\section{Література:}

1. Абдурахманов Д.Б. Политическая турбулентность в условиях глобализации: поиски теоретического концепта. Общественные науки. 2014. № 3. С. 17-20. URL: https://elibrary.ru/download/elibrary_21685693_36287209.pdf (дата звернення: 19.12.2020).

2. Делокаров К.Х. Системная парадигма современной науки и синергетика. Общественные науки и современность. 2000. № 6. C. 110-118. URL: http://ecsocman.hse.ru/data/678/235/1218/009dELOKAROW.pdf (дата звернення: 20.12.2020).

3. Пожалов А.А. Исследования политического риска: история зарождения, становлення и развития. Вестник Московского университета. Серия 12. Политические науки. 2006. № 3. С. 43-56.

4. Кривошеїн В.В. Політична ризикологія: епістемологічний статус, предметна сфера, аналітичні інструменти : монографія. Дніпропетровськ : Інновація, 2009. 316 с.

5. Пригожин И., Стенгерс И. Порядок из хаоса: Новый диалог человека с природой / пер. с англ. ; общ. ред. В.И. Аршинова, Ю.Л. Климонтовича и Ю.В. Сачкова. Москва : Прогресс, 1986. 432 с.

6. Emery F.E., Trist E.L. The causal texture of organizational environments. Human Relations. 1965. Vol. 18 P. 21-32. URL: https://ackoffcenter.blogs.com/ackoff_center_weblog/files/10.1177_001872676501800103.pdf (дата звернення: 19.12.2020).

7. Популях Д.С. Турбулентность в современной мировой политике: дискурсы и практика : дис. ... канд. полит. наук : 23.00.04; Моск.гос.ун-т имени М.В. Ломоносова. Москва, 2016.173 c. URL: https://istina.msu.ru/dissertations/30283758/ (дата звернення: 17.12.2020).

8. Rosenau J.N. Turbulence in World Politics. A Theory of Change and Continuity. Princeton, New Jersey : Princeton University Press, 1990. $480 \mathrm{p}$.

9. Евдоченко Е.А. Турбулентность глобальной экономической среды: теоретические аспекты и практическое проявление. URL: https://docplayer.ru/44615372-Turbulentnost-globalnoy-ekonomicheskoy-sredy-teoreticheskie-aspekty-iprakticheskoe-proyavlenie.html (дата звернення: 18.12.2020). 